\title{
Bioremediation for a Soil Contaminated with Hydrocarbons
}

\section{Rosario Iturbe* and Jessica López}

Remediation of Soils and Aquifers Group, Universidad Nacional Autónoma de México, Apartado Postal 70-472, Circuito Interior Ciudad Universitaria, Coyoacán 04510, Mexico

\begin{abstract}
The objective was to remediate, through biopiles, $27400 \mathrm{~m}^{3}$ of soil contaminated with heavy fraction hydrocarbons $(\mathrm{HFH})$ at a Maritime Terminal in southeastern Mexico. To clean the soil, two bioremediation stages were considered: i) batches of soil of $3800 \mathrm{~m}^{3}$ subjected to land farming pretreatment, ii) biopiles formation of $70 \mathrm{~m}$ length, $16 \mathrm{~m}$ width, and $2 \mathrm{~m}$ height. The parameters controlled during 8 months of bioremediation were: nutrients, water content, aeration, and temperature. Monitoring contemplated monthly sampling of each biopile, the analyzed parameters were the heavy fraction hydrocarbons, bacteria counting, and respirometry. Results revealed that $\mathrm{HFH}$ removal in biopiles reached $43.2 \%$ after pre-treatment (land farming), $68.7 \%$ at mid-treatment, and $77.7 \%$ at the end of treatment. The land farming pretreatment achieved a higher percentage of hydrocarbons removal, because aeration was very efficient at the start of treatment; therefore, enhancing aerobic biodegradation.
\end{abstract}

Keywords: Bioremediation; Biopiles; Land farming; Contaminated soil; Hydrocarbons degradation; Heavy fraction hydrocarbons

\section{Introduction}

Bioremediation of soils is currently a relevant issue, because it implies a process in which organic contaminants in the subsoil are biodegraded and can become mineralized so that eventually they become non-toxic compounds. The contaminant does not enter another physical state because it is degraded.

Bioremediation is aimed at maintaining the maximal possible growth of microorganisms until the carbon source (organic contaminant) decreases and, consequently, the microbial population decreases [1].

Physical and chemical factors are needed for an efficient bioremediation process; including water, temperature, $\mathrm{pH}$, oxygen, major and minor nutrients.

- Water: Water content is one of the most important factors for degradation, since water constitutes 80 to $90 \%$ of the weight in the molecular composition of bacterial cells and is the main nutrient [2].

- $\quad$ Ph: The intracellular $\mathrm{pH}$ value lies between 6.5 and 7.5 , hence this is the required $\mathrm{pH}$ range needed for optimal microorganisms' growth.

- Temperature: The chemical and enzymatic reactions of the cell increase concomitantly with increasing temperature. There are: a minimal temperature for each organism, below which no growth occurs, an optimal temperature at which growth is faster, and a maximal temperature above which no more growth occurs. The temperature range considered optimal for heterotrophic aerobic bacteria is between $20^{\circ} \mathrm{C}$ and $35^{\circ} \mathrm{C}[3]$.

- Oxygen: Oxygen is the electron acceptor most used by microorganisms to degrade organic compounds in an aerobic environment. If the oxygen content of the soil is below $2 \mathrm{mg} / \mathrm{l}$, conditions are favorable for an anaerobic environment.

- $\quad$ Nutrients: The solid portion of the bacterial cell is constituted by carbon, nitrogen, hydrogen, phosphorus, and, to a smaller extent, potassium, calcium, magnesium, chlorides, iron, and others. The main component $(50 \%)$ is carbon. The contaminant to be degraded must contain this element. Oxygen, with $20 \%$, is the second most abundant element in the cell. Oxygen is needed for new cells and as electron acceptor, hence, it is necessary to count upon large amounts of oxygen for biological degradation. The other major nutrients required by microorganisms are nitrogen and phosphorus. The three main nitrogen sources in microorganisms are proteins, cell wall constituents, and nucleic acids. Phosphorus, in the form of phosphates, is used by microorganisms to synthesize phospholipids and nucleic acids [4].

Factors that might limit the activity of microorganisms are low temperatures, very low o very high $\mathrm{pH}$ values, chemical agents, such as heavy metals, halogens, organic and oxidizing contaminants.

The main techniques applied to bioremediation are: in situ bioremediation, biopiles, landfarming, phytoremediation, bioaugmentation, bioventing.

The biopiles technique consists in forming piles with the contaminated soil and stimulating the microbial communities through aeration and/or by adding nutrients and water. The increment in microbial activity is directly proportional to the reduction in heavy fraction hydrocarbon $(\mathrm{HFH})$ concentrations. Biopiles are aimed at reducing the concentration of hydrocarbons that are adsorbed in contaminated soils by means of biodegradation [5]. Biopiles is the most commonly used technique to treat soils contaminated with petroleum hydrocarbons, especially soils having a predominantly sandy granulometry [6-8].

Microbiological activity can be stimulated by supplying oxygen, through aeration, and water and nutrients, such as nitrogen and phosphorus.

*Corresponding author: Rosario Iturbe, Remediation of Soils and Aquifers Group Universidad Nacional Autónoma de México, Apartado Postal 70-472, Circuito Interior Ciudad Universitaria, Coyoacán 04510, Mexico, Tel: 52(55)56233671; E-mail: ria@pumas.iingen.unam.mx

Received October 06, 2014; Accepted February 28, 2015; Published March 07, 2015

Citation: Iturbe R, López J (2015) Bioremediation for a Soil Contaminated with Hydrocarbons. J Pet Environ Biotechnol 6: 208. doi:10.4172/2157-7463.1000208

Copyright: ( 2015 Iturbe R, et al. This is an open-access article distributed under the terms of the Creative Commons Attribution License, which permits unrestricted use, distribution, and reproduction in any medium, provided the original author and source are credited. 
Efficiency of a biopile depends on several parameters, which are grouped in three categories (Fahnestock et al, 1998), these are:

1. Soil characteristics.

2. Characteristics of the contaminants.

3. Weather conditions.

The type of soil is very important because water, nutrients, and air must be able to migrate with some ease through the soil pores to allow microorganisms to accomplish degradation. Texture of the soil influences soil permeability, water content, and soil density. Highly permeable soils are the most easily aerated and, therefore, are the most adequate to be used for biopiles.

Biopiles are constructed on an impermeable base to reduce the possible migration of lixiviates towards the subsoil. In addition, a network of perforated tubes are installed within the biopile and connected to an aeration system to allow air penetration into the soil and supplying air to bacteria.

\section{Nature of soil contamination}

The objective of this work was to clean a soil contaminated with hydrocarbons by means of bioremediation, at a contaminated site located within a PEMEX facility in the state of Tabasco, in southeastern Mexico, where the largest petroleum extraction and production processes of the country are carried out.

Soil contamination was present on the site, predominantly as petroleum hydrocarbons. This contamination resulted from storage and handling of fuels and residual petroleum from storage tanks. The petroleum hydrocarbons were heavier fractions (HFH) (C15-C36) than expected from the nature of the activities on the site, with concentrations of up to $20000 \mathrm{mg} / \mathrm{kg}$.

Two areas of soil contamination were identified requiring remediation. Zone A and Zone B (Figure 1). The site had been contaminated since 40 years ago due to inadequate storage practices. The bioremediation area (Zone C) was located at $300 \mathrm{~m}$ from Zone B.

The contaminated site, at the Marine Terminal “Dos Bocas”, in the state of Tabasco, is located in an area of $11150 \mathrm{~m}^{2}$, with an irregular depth between 1 and $6 \mathrm{~m}$, with an average hydrocarbons concentration of $20000 \mathrm{mg} / \mathrm{kg}$, and a contaminated volume of $27400 \mathrm{~m}^{3}$. Remediation
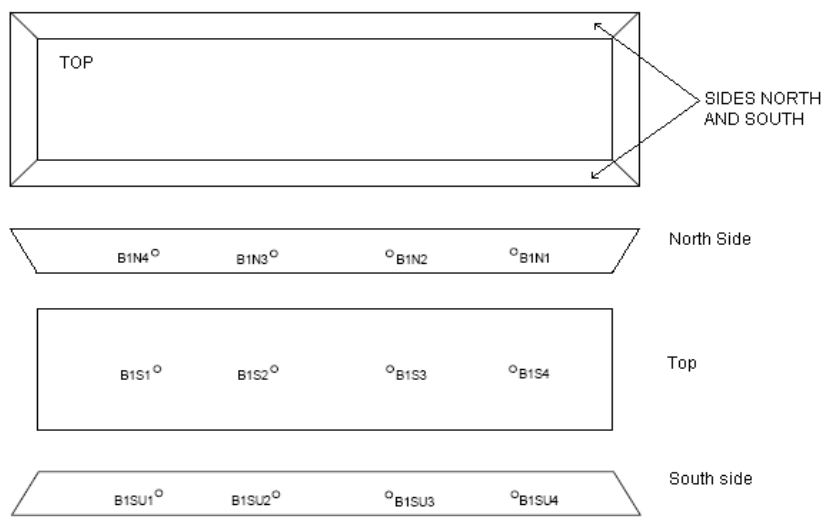

Note: $\mathrm{B}=\mathrm{B}$ iopile; $1=$ Biopile number; $\mathrm{SU}=\mathrm{South}, \mathrm{S}=\mathrm{Top}, \mathrm{N}=\mathrm{North} ; 1=$ Number of sampling points

Figure 1: View of biopiles design and sampling points. of the soil involved excavation of all the soil exceeding $6000 \mathrm{mg} / \mathrm{kg}$ of heavy fraction hydrocarbons, as specified by the Mexican normativity. The water table was found at an average of $3.40 \mathrm{~m}$ depth.

\section{Materials and Methods}

At the start of the work, the soil was characterized and its main parameters $(\mathrm{pH}$, porosity, organic matter content, soil granulometry, water content, content of heterotrophic bacteria) were determined.

To clean the soil, two bioremediation stages were considered: i) batches of soil were prepared with an approximate volume of $3800 \mathrm{~m}^{3}$ that were pretreated through land farming. In this stage, the necessary calculated nutrients were mixed and added to the soil; the soil was aerated and mechanically homogenized during 28 days to go over to the second stage. ii) The second stage consisted of forming biopiles of $70 \mathrm{~m}$ length, $16 \mathrm{~m}$ width, and $2 \mathrm{~m}$ height. The general procedure was as follows.

\section{Extraction and separation of the clean soil}

The clean soil was separated from the contaminated soil in the study area, starting at the point where contamination was observed. During this activity, it was observed that the distribution of the contamination was very variable, since there were zones in which contamination appeared at $0.7 \mathrm{~m}$ depth, whereas, in other zones, the contaminated soil appeared at more than $4.0 \mathrm{~m}$ depth. The clean soil was carried over from Zone A to Zone B, where it was maintained until the time was deemed adequate to fill-out the cleaned areas. Separation of the clean soil from the contaminated one was performed based on the organoleptic characterization, and considering the results of the samples sent to a certified laboratory to be analyzed.

\section{Extraction and transportation of the contaminated soil}

The contaminated soil was extracted in land strips of approximately $15 \mathrm{~m}$ width, with a Caterpillar 320 excavator, until a depth ranging from 5.0 to $6.50 \mathrm{~m}$. The criterion to stop excavation consisted in collecting samples at the excavated depths for analysis and once the analytical results indicated that the HFH values where within the maximal permissible limits (MPL), according to the Mexican normativity; continuing, then, with the next strip of land.

- Cleaned areas: Once reaching the depth at which no contamination was detected, the area was filled with the initially separated clean soil that had been stored at the same site.

- $\quad$ Soil-sieving: Once the contaminated soil had been extracted and separated from the clean soil, it was carried over to Zone C, where the final separation of thick materials existing in the soil was performed by means of a $4 \mathrm{~m}$ wide, $3.5 \mathrm{~m}$ high, and $8 \mathrm{~cm}$ mesh-size soil-sieve.

- Land farming (pretreatment): Once the soil had been sieved, it was taken to the homogenization, aeration, and nutrients addition processes. To optimize soil conditions, the soil was mixed and aerated mechanically, and nutrients were added according to a C:N:P ration of 100:10:1, to promote the biodegradation process of the contaminants.

- Calculations were based on the initial HFH concentration of $20000 \mathrm{mg} / \mathrm{kg}$, considering a carbon concentration of $16000 \mathrm{mg} /$ $\mathrm{kg}(80 \%$ of $\mathrm{HFH})$ and adjusting the effective nutrients content in the agricultural fertilizers used for this purpose.

- Biopiles: Before starting the biopile construction, a high density, $1-\mathrm{mm}$ thick polyurethane liner was placed as bedding to protect the subsoil from an eventual generation and migration of 
leachate. Each biopile was $60-\mathrm{m}$ long, $16-\mathrm{m}$ wide, 2 -m high, with a 1:1 slope. They were constructed in layers of $40-\mathrm{cm}$ thickness and at the end of each layer, a grooved 1-inch diameter PVC tube was placed along the width of the biopile, at a 3.50-m distance, to provide air inside the biopile.

- Aeration system: Oxygen (2 kg) is needed for each kilogram of hydrocarbons. The constructed biopiles had a volume of $1624 \mathrm{~m}^{3}$, each, and a bulk density of $1.6 \mathrm{ton} / \mathrm{m}^{3}$; i.e., a mass of 2598 ton. Hence, each biopile contained $36372000 \mathrm{~kg}$ of hydrocarbons, that means that a supply of 83 ton of $\mathrm{O}_{2}$ is needed. It is considered that this amount of air should be supplied in 150 days, at a flow of $553 \mathrm{~kg} / \mathrm{day}=384 \mathrm{~g} /$ min. In a work performed, at an actual scale, in biopiles bioremediation of soils contaminated with hydrocarbons, a compressor-aided aeration system was used with a volumetric flow of $0.006 \mathrm{~m}^{3} / \mathrm{s}$, determined in previous studies as the flow required every $24 \mathrm{~h}[9]$.

Because of the high temperatures at the site, together with the temperature at the compressors output $\left(50^{\circ} \mathrm{C}\right)$, it was necessary to design a cooling system to be placed on the output of the compressor. In this way, the average temperature of the air at the entrance to the biopile was $30^{\circ} \mathrm{C}$, which is an adequate temperature for the growth of the microorganisms in charge of degrading the contaminant.

Biopiles were maintained at optimal conditions by means of an aeration system and water supply using constant irrigation. To protect the biopiles, a gravel layer was added at the end of the construction, placed on the surface, to avoid erosion of the biopile's soil by wind and rain.

\section{Soil sampling of biopiles}

To assess periodically the $\mathrm{HC}$ concentrations in each biopile, these were monitored monthly. Twelve sampling points were considered at each biopile, at three different depths in the lateral sides of the biopile $(0.5,1.5$, and $2.5 \mathrm{~m})$ and at $0.5,1.2$, and $1.8 \mathrm{~m}$ depth in the upper side, as shown in Figure 1. That is, 36 samples were obtained from each biopile; by making a compound sample at each depth, nine samples are obtained for analyses.

\section{Results and Discussion}

Table 1 presents the results of the physical, chemical, and biological parameters of the soil.

\section{Removal of heavy fraction hydrocarbons}

At the start of the project, once the contaminated soil had been

\begin{tabular}{|c|c|c|}
\hline Parameter & Analytical method & Result \\
\hline HFH & $\begin{array}{c}\text { EPA9071-B for HFH extraction } \\
\text { EPA 1664A for chromatographic } \\
\text { analysis }\end{array}$ & Table 3 \\
\hline Bulk density $\left(\mathrm{g} / \mathrm{cm}^{3}\right)$ & $\begin{array}{c}\text { Method AS 03 } \\
\text { (NOM-021-RECNAT-2000) }\end{array}$ & 1.2451 \\
\hline Dry density $\left(\mathrm{g} / \mathrm{cm}^{3}\right)$ & ASTM; D854-83 & 2.6086 \\
\hline Porosity $(\%)$ & $\begin{array}{c}\text { Difference between bulk and dry } \\
\text { density }\end{array}$ & 0.52 \\
\hline pH & ASTM-D 4972-89 & 7.16 \\
\hline Organic carbon fraction, $\mathrm{f}_{\text {oc }}(\%)$ & $\begin{array}{c}\text { Method AS 07 } \\
\text { (NOM-021-RECNAT-2000) }\end{array}$ & 2.281 \\
\hline Organic matter (\%) & $\begin{array}{c}\text { Method AS 07 } \\
\text { (NOM-021-RECNAT-2000) }\end{array}$ & 3.965 \\
\hline Granulometric analysis & SUCS (ASTM, D 422) & Sand \\
\hline Count of aerobic bacteria \\
$($ CFU/g) & NOM-092-SSA1-1994 & $8 \times 10^{8}$ \\
\hline
\end{tabular}

Table 1: Physical, chemical, and biological parameters of the contaminated soil.

\begin{tabular}{|c|c|c|c|c|c|c|c|c|}
\hline KEY & START (2008) & M1 & M2 & M3 & M4 & M5 & M6 & M7 \\
\hline BP1 & Jan & Apr & --- & --- & --- & --- & --- & --- \\
\hline BP2 & Mar 10 & Apr & May & Jun & Jul & Aug & Oct & Dec \\
\hline BP3 & Mar 10 & Apr & May & Jun & Jul & Aug & Oct & Dec \\
\hline BP4 & Apr 18 & May & Jun & Jul & Aug & Dec & --- & --- \\
\hline BP5 & Apr 19 & May & Jun & Jul & Aug & Dec & --- & --- \\
\hline BP6 & May 15 & Jun & Jul & Aug & Dec & --- & --- & --- \\
\hline BP7 & May 22 & Jun & Jul & Aug & Dec & --- & --- & --- \\
\hline BP8 & Jun 27 & Jul & Aug & Dec & --- & --- & --- & --- \\
\hline BP9 & Jun 2 & Jun & Jul & Aug & Oct & Dec & --- & --- \\
\hline BP10 & Jun 27 & Jul & Aug & Dec & --- & --- & --- & --- \\
\hline BP11 & Jul 8 & Jul & Aug & Dec & --- & --- & --- & --- \\
\hline BP12 & Jul 15 & Aug & Dec & --- & --- & --- & --- & --- \\
\hline BP13 & Jul 25 & Aug & Dec & --- & --- & --- & --- & --- \\
\hline BP14 & Aug 10 & Dec & --- & --- & --- & --- & --- & -- \\
\hline
\end{tabular}

Table 2: Sampling frequencies of biopiles.

\begin{tabular}{|c|c|c|c|c|}
\hline Biopile & $\begin{array}{c}\text { Initial } \\
\text { average }^{1}\end{array}$ & $\begin{array}{c}\text { After } \\
\text { pretreatment }{ }^{2}\end{array}$ & $\begin{array}{l}\text { Mid-treatment } \\
\text { average }^{3}\end{array}$ & Final average $^{3}$ \\
\hline 1 & 20213 & 9978 & SD & 3556 \\
\hline 2 & 20213 & 12465 & 6434 & 5171 \\
\hline 3 & 20213 & 12465 & 7091 & 5610 \\
\hline 4 & 20213 & 12465 & 4944 & 3580 \\
\hline 5 & 20213 & 12465 & 5302 & 3579 \\
\hline 6 & 20213 & 11393 & 7685 & 4899 \\
\hline 7 & 20213 & 11393 & 7755 & 5098 \\
\hline 8 & 20213 & 6780 & 6093 & 3966 \\
\hline 9 & 20213 & 12700 & 7748 & 5541 \\
\hline 10 & 20213 & 12700 & 5313 & 4588 \\
\hline 11 & 20213 & 13660 & 6030 & 4043 \\
\hline 12 & 20213 & 11308 & 5491 & 5089 \\
\hline 13 & 20213 & 11308 & 5995 & 5410 \\
\hline 14 & 20213 & 9657 & SD & 3032 \\
\hline
\end{tabular}

${ }^{1}$ Results of the soil sample from the original site, taken by the quartering method ${ }^{2}$ Results of the soil sample for each constructed biopile at mid-time of treatment ${ }^{3}$ Average results of sampling on the three sides and the three depths of the biopile $\mathrm{SD}=\mathrm{No}$ data, $\mathrm{HFH}=$ Heavy fraction hydrocarbons

Table 3: Summary of HFH concentrations in biopiles $(\mathrm{mg} / \mathrm{kg})$.

sieved and stored, 10 samples were taken from diverse portions of the stored soil. Two compound samples were obtained and considered as the initial concentration of the contaminated soil. The average concentration obtained was of $20213 \mathrm{mg} / \mathrm{kg}$.

In another work, bioaugmentation and natural attenuation were tested as remediation strategies in biopiles, sampled periodically until reaching 182 days. Biopiles were divided in quadrants and samples taken from each quadrant, then compound samples from the first samplings were made and sieved to separate the fraction equal or smaller than $2 \mathrm{~mm}$ [10]. Other authors tested composting in once constructed; biopiles were sampled as shown in Table 2 .

Table 3 shows the average results obtained from the heavy fraction hydrocarbons monitoring. Results obtained in each biopile were averaged.

Biopiles for bioremediation of hydrocarbons-contaminated soil. To sample the biopiles that were 2 to $4 \mathrm{~m}$ high, a compound sample was made for each biopile constituted by 10 to 12 simple samples, which were then homogenized and sieved to take the sample [11].

Monitoring results revealed that HFH removal in biopiles reached an average of $43.2 \%$ after pre-treatment (landfarming), $68.7 \%$ at mid- 
treatment, and $77.7 \%$ at the end of treatment. It must be noted that $\mathrm{HFH}$ concentrations in the biopiles were different because the soil, although coming from the same area, was from different locations and depths, and had different initial HFH concentrations. Removal was reached after 4 to 9 months of soil treatment. This effect has been studied previously, achieving reductions of $2400 \mathrm{mg} / \mathrm{kg}$ to $700 \mathrm{mg} \mathrm{kg}^{-1}$ in 5 months, which represents an average of $70 \%$ reduction.

It is considered that the reduction of contaminants was through degradation as they are heavy fraction hydrocarbons and contain no volatile compounds, or might have them at a very low proportion. It has been reported that the portion of hydrocarbons (mid and heavy fraction) reduced due to volatilization is, in general, less than $10 \%$ at $25^{\circ} \mathrm{C}$ during the first 30 days [12].

For biopile 1, the first sampling revealed that the HFH concentrations were already below the maximal permissible limits (MPL) indicated by the NOM-138-SEMARNAT/SS-2003 for HFH from industrial-use soil (6000 mg/kg of soil) (DOF, 2005). Therefore, after the third sampling, in which no contaminants were found, the biopile was dismantled and the clean soil was carried over to the original site to be used as filling material. This fast response could have been due to the fact that the soil extracted for this biopile did not have a high HFH concentration at the start and came from the surface of the contaminated site, where the soil is enriched with aerobic microbial populations with a high potential for hydrocarbons degradation and a higher content of nutrients, as well as better aeration; thus, by stimulating the microbial population with optimal conditions, the contaminant was degraded faster.

The maximal degradation of organic contaminants is usually achieved in the first 2 months; this pattern is similar in soils contaminated with both types of hydrocarbons, mid and heavy fraction. This same pattern has been reported by many authors independently from the initial concentration [11].

Other researchers have reported $48 \%$ degradation from an initial total petroleum hydrocarbon (TPH) concentration of $10000 \mathrm{mg} / \mathrm{kg}$ $[13,14]$. These were field-scale biopiles with wood chips as bulking agent. Bench-scale experiments from the same site showed a slightly more effective degradation of $80 \%$ [15], but still the same pattern.

Biopiles 2 and 3 were the slowest ones in responding to the cleaning treatment, they yielded results below the MPL until the sixth month of treatment; this can have been due to the higher initial concentration and because the soil came from deeper layers, reaching the phreatic level. In this stratum, the particles size is much smaller than at the surface, corresponding to a clayish-lime stratum; hence, oxygen transfer at this level is so low that it does not allow for the survival of aerobic microbial populations. We believe that the bacteria that might have been stimulated were facultative populations with some potential for hydrocarbons degradation, which, when subjected to optimal aerobic condition, were able to develop and degrade the contaminant; however, the developing process was slower than if the organisms had been strictly aerobic. In biopiles with different aeration systems, it has been demonstrated that a high water content has a negative impact on de biodegradation process; hence, more air has to be introduced than that naturally entering the biopiles [16].

In biopiles $4,5,6$, and 7 , results were below the MPL between the third and fourth month of treatment. The behavior was the expected one, because they were within the time range theoretically assumed for a biopile under the conditions of the site described herein. Although the soil could have contained also fine fractions, the speed at which the soil was extracted was higher than the speed at which the biopiles were constructed; hence, the soil was under aerobic conditions for a longer time than biopiles 2 and 3 . Thus, it is assumed that the microorganisms had a longer adaptation time, and when the biopiles were constructed after the pretreatment, the developing stage of the microorganisms could have been optimal, and degradation of contaminants was not so slow. Other authors have demonstrated the importance of aeration in this type of treatments, since their experiments with aeration reached a reduction of up to $95 \%$ in the first or second month of treatment, as compared to the control without aeration that did not depict a significant reduction in contaminants concentration [17-19].

For biopiles 8, 9, and 11, values near the MPL were obtained in the second month of sampling, but, on the next sampling, they showed an 8 to $10 \%$ increase, to finally decrease and reach concentrations below the MPL after 4 months. This increase could be attributed to the fact that heavy rains occurred during pretreatment and construction stages of these biopiles, which could have induced soil-washings, causing a higher availability of hydrocarbons that was reflected in an increase in concentration; however, since the increase in concentration was not too large, it did not cause a negative impact on the microbial population, reaching sufficient removal of hydrocarbons.

For biopiles 10,12, and 13, the initial concentrations were very close to the MPL, and the removal was slow, but did reach the MPL, this could have been due to the fact that the degradation rate becomes slower with low hydrocarbons concentration.

Biopile 14 was the one to reach concentrations very much below the MPL in the shortest time, as established by the NOM-138-SEMARNAT/ SS-2003 for HFH from industrial-use soil $(6000 \mathrm{mg} / \mathrm{kg}$ of soil) with an $85 \%$ removal at two months. It must be noted that this biopile had a passive aeration system through the vertical and horizontal installation of grooved tubes, placing cones to catch the wind from the dominant direction on the upper ends of the tubes.

The following graphs depict the behavior of 3 of the 14 constructed biopiles. These three were chosen, considering that they are the most representative ones (Figures 2-4).

\section{Microbiological results}

A microbiological assessment was performed at the start of the project, consisting in bacteria counting tests based on the platecounting method indicated by the NOM-092-SSA1-1994 [20]. These tests were applied to representative samples considered as initial samples and collected by the quartering method.

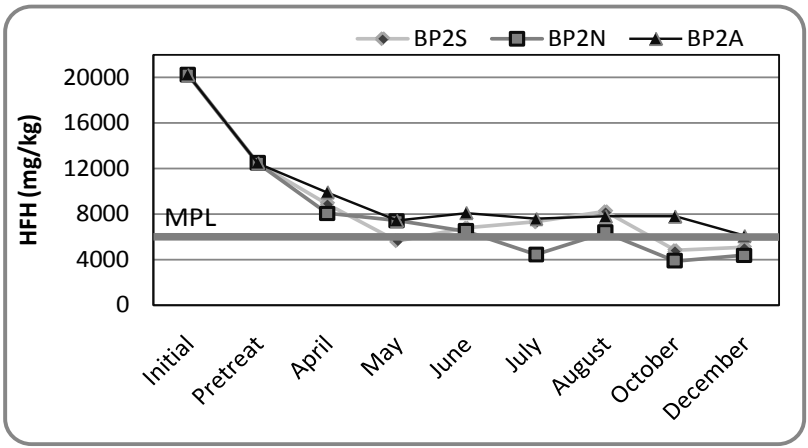

${ }^{*} \mathrm{MPL}=$ Maximum permissible limit

Figure 2: Behavior of biopile 2 in the studied time. 


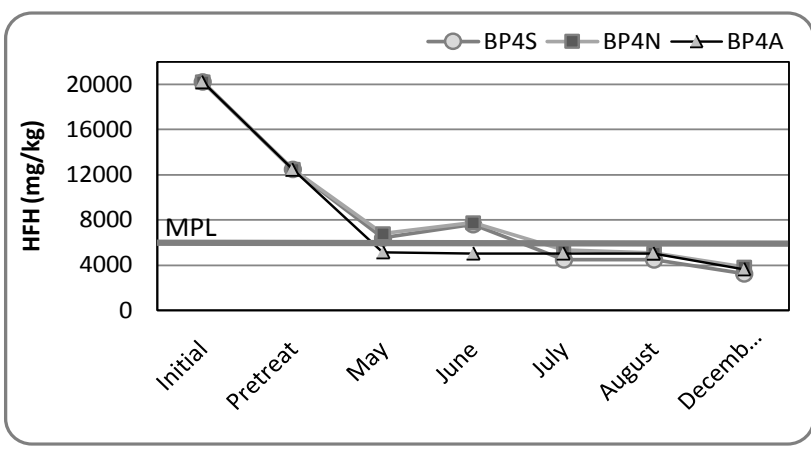

${ }^{*} \mathrm{MPL}=$ Maximum permissible limit

Figure 3: Behavior of biopile 4 in the studied time.

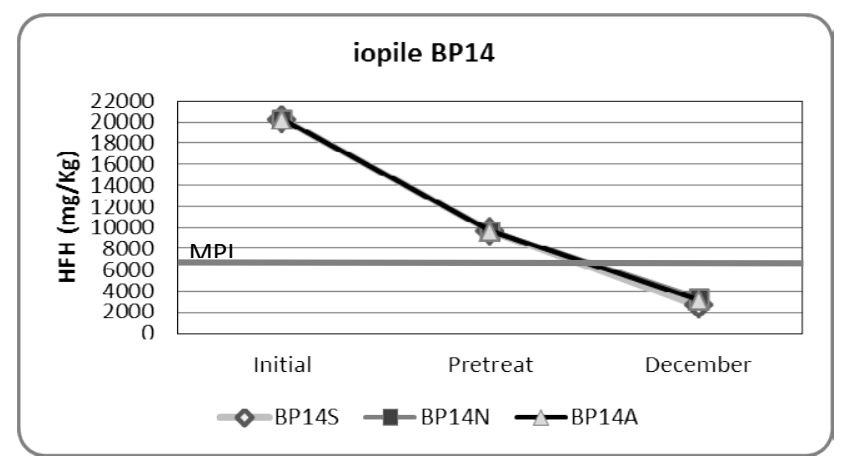

*MPL=Maximum permissible limit

Figure 4: Behavior of biopile 14 in the studied time.

\begin{tabular}{|c|c|c|c|}
\hline BIOPILE & $\begin{array}{c}\text { INITIAL } \\
\text { AVERAGE }\end{array}$ & $\begin{array}{c}\text { MID-TREATMENT } \\
\text { AVERAGE }\end{array}$ & FINAL AVERAGE \\
\hline $\mathbf{1}$ & $2 \times 10^{3}$ & $2.6 \times 10^{3}$ & $2.8 \times 10^{5}$ \\
\hline $\mathbf{2}$ & $1.1 \times 10^{3}$ & $3.8 \times 10^{5}$ & $4.5 \times \times \times 10^{5}$ \\
\hline $\mathbf{3}$ & $2 \times 10^{3}$ & $4.6 \times 10^{6}$ & $3.7 \times 10^{4}$ \\
\hline $\mathbf{4}$ & $2 \times 10^{3}$ & $1.2 \times 10^{6}$ & $3.6 \times 10^{4}$ \\
\hline $\mathbf{5}$ & $2 \times 10^{3}$ & $1.4 \times 10^{6}$ & $2.4 \times 10^{4}$ \\
\hline $\mathbf{6}$ & $2 \times 10^{3}$ & $2.7 \times 10^{6}$ & $2.0 \times 10^{5}$ \\
\hline $\mathbf{7}$ & $3.5 \times 10^{3}$ & $2.7 \times 10^{6}$ & $3.4 \times 10^{6}$ \\
\hline $\mathbf{8}$ & $2.8 \times 10^{3}$ & $3.1 \times 10^{6}$ & $3.1 \times 10^{4}$ \\
\hline $\mathbf{9}$ & $1.3 \times 10^{3}$ & $3.2 \times 10^{6}$ & $2.6 \times 10^{5}$ \\
\hline $\mathbf{1 0}$ & $1.6 \times 10^{3}$ & $1.6 \times 10^{5}$ & $3.9 \times 10^{5}$ \\
\hline $\mathbf{1 1}$ & $2.1 \times 10^{3}$ & $3.8 \times 10^{6}$ & $3.4 \times 10^{5}$ \\
\hline $\mathbf{1 2}$ & $3.6 \times 10^{3}$ & $8.2 \times 10^{5}$ & $6.7 \times 10^{5}$ \\
\hline $\mathbf{1 3}$ & $1.3 \times 10^{3}$ & $6.3 \times 10^{5}$ & $1.4 \times 10^{5}$ \\
\hline $\mathbf{1 4}$ & $2 \times 10^{3}$ & $3.5 \times 10^{5}$ & $2.3 \times 10^{5}$ \\
\hline
\end{tabular}

Table 4: Summary of colony forming units per gram of soil (CFU).

The number of Colony Forming Units (CFU) per gram of soil obtained from these samples were in the order of 103, which is considered low; however, it is considered that the minimum of CFU/g for degradation to occur is equal or higher than 102; therefore, to stimulate the development and growth of bacteria, moisture, aeration, and nutrient conditions were optimized [21] (Table 4).

This low initial CFU count, despite dealing with a site of very favorable conditions for bacterial growth, could have been originated because a large part of the extracted soil came from a saturated zone limited by a clayed-lime stratum, which gives the aquifer characteristics of low oxygen transfer, hence the number of aerobic bacteria, which are the ones considered for the aforementioned tests, was quite low.

During the bioremediation treatment, the number of CFU found increased gradually until reaching an optimal amount for the specific conditions of the treatment, which favored degradation of the hydrocarbons present in the soil. In average, the number of CFU increased in two to three orders of magnitude in all biopiles. Some authors, who performed an experiment to compare conventional aeration with a new system proposed by them, found that the heterotrophic microbial population, after 15 days of treatment, increased one order of magnitude, decreasing afterwards, which is a common pattern of bacterial growth [22].

The microbiological analysis was complemented with the identification of bacteria, of which eight species could be isolated and identified. These species are considered to be hydrocarbons degrading bacteria, and were: Vibrio metschnikovii, Micrococcus kristinae, Pseudomonas luteola, Bacillus brevis, Bacillus megaterium, Bacillum licheniformes, Pseudomonas aeruginosa, Flavimonas orzyhabitans. Identification was achieved with BBL and API kits.

Respirometry values in the biopiles, in which $\mathrm{CO}_{2}$ generation could be observed and is indicative of biodegradation, were in the 2.46 to 4.0 $\mathrm{mg} \mathrm{CO} / \mathrm{kg}$ of soil per day range, which, according to some authors [23], corresponds to a low degradation rate, but which sufficed to attain results with HFH, complying with the established normativity. However, other authors report lower respirometry values and consider them to represent an adequate degradation activity. An author reported a degradation rate from $32 \mu \mathrm{g} \mathrm{CO} / \mathrm{g}$ soil to $150 \mu \mathrm{g} \mathrm{CO} / \mathrm{g}$ soil, after 61 to 161 days of incubation in five different treatments [24].

The factors that influence biodegradation ( $\mathrm{pH}$, energy source, soil temperature, water and nutrients content, aeration) are discussed in the following.

- The basic energy source in this project was constituted by hydrocarbons, since the organic matter content of the soil was very low as to constitute an important energy source.

- The $\mathrm{pH}$ of the soil (7.16) was within the indicated range (6.5-7.5).

- Temperature of soil in the biopiles. This temperature increased once the nutrients were added. During pretreatment, the soil temperature was of $18^{\circ} \mathrm{C}$, increasing in the biopiles to $22^{\circ} \mathrm{C}$, in average.

- $\quad$ Aeration. Air supply was calculated to obtain the required oxygen of $2 \mathrm{~kg} \mathrm{O} / 2 \mathrm{~kg}$ of $\mathrm{HFH}$. However, the possibility that anaerobic degradation could have occurred in the center of the biopile cannot be discarded because of the presence of $\mathrm{CO}_{2}$ generated in the aerobic zone.

- Nutrients (nitrogen and phosphorus) supplemented through the commercial fertilizers were an important substrate source to facilitate degradation. For $16000 \mathrm{mg} / \mathrm{kg}$ carbon content, nitrogen was added at $1150 \mathrm{mg} / \mathrm{kg}$ since the concentration of the site's soil was 450 $\mathrm{mg} / \mathrm{kg}$, and the added phosphorus content was of $157 \mathrm{mg} / \mathrm{kg}$ since the original P concentration was of $3 \mathrm{mg} / \mathrm{kg}$. With this, the C:N:P ratio of 100:10:1 was attained.

\section{Conclusion}

The biopiles remediation method applied to the Marine Terminal "Dos Bocas", in the state of Tabasco, resulted adequate to remove hydrocarbons in $27400 \mathrm{~m}^{3}$ of soil, since the final HFH concentrations were below the maximum permissible limits established by the NOM- 
Citation: Iturbe R, López J (2015) Bioremediation for a Soil Contaminated with Hydrocarbons. J Pet Environ Biotechnol 6: 208. doi:10.4172/21577463.1000208

138-SEMARNAT/SS-2003, which for an industrial-use soil is of 6000 $\mathrm{mg} / \mathrm{kg}$. By controlling the factors that influence biodegradation, it was possible to stimulate the native microorganism's population of the site to favor biodegradation of the hydrocarbons present in the soil. The climate and the sandy soil characteristics of the zone, where the Marine Terminal "Dos Bocas", in Tabasco, is located, are ideal for the application of biopiles. With the land farming pretreatment, a higher percentage of hydrocarbons removal can be achieved. Aeration was very efficient at the start of treatment; hence, it is considered that the biodegradation is aerobic. The time at which permissible concentrations were reached was less than six months.

\section{Acknowledgment}

The authors express their sincere appreciation to Carlos Flores, who was responsible for the work on the site, and the author of the passive aeration for biopile 14; to Lilia Corona and Alma Cortés, who were responsible for microbiology testing. Thanks are due to Jesús Flores, Julio Barroso, Israel Flores, Daniel Flores, and Ricardo Ramírez, who controlled the biopiles operation.

\section{References}

1. Suthersan S (1997) Remediation Engineering Design Concepts. Lewis Publishers, USA

2. Nyer E (2001) In situ treatment technology. Lewis Publishers, USA.

3. Yong R, Mulligan C (2004) Natural Attenuation of Contaminants in Soils. Lewis Publishers, USA.

4. Suthersan S (2002) Natural and enhanced remediation systems. Lewis Publishers, USA.

5. Domenico P, Schwartz (1990) Physical and Chemical Hydrogeology. John Wiley and Sons, USA.

6. Cookson J (1995) Bioremediation Engineering. Design and Application McGraw-Hill Inc, USA.

7. Martin I, Bardos P (1996) A review of Full Scale Treatment Technologies for the Remediation of Contaminated Soil. EPP Publications, Lansing MI.

8. Patterson B, Davis G, Briegel D (1999) Use of Respirometry Tests to Monitor Bioventing Remediation of Hydrocarbon Contaminated Soils. In: Johnston C (Ed.), Contaminated Site Remediation: Challenges posed by Urban and Industrial Contaminants, CSIRO, Perth Australia.

9. Quinn JW, Reinhart DR (1997) Bioremediation of Diesel Contaminated Soil Using Biopiles. Pract Period Hazard Toxic Radioact Waste Manag 1: 18-25.

10. Juhasz A, Waller N, Lease C, Bentham R, Stewart R (2005) Pilot Scale
Bioremediation of Creosote-Contaminated Soil-Efficacy of Enhanced Natural Attenuation and Bioaugmentation Strategies. Bioremediat J 9: 141-157.

11. Jorgensen K, Puustinen J, Suortti A (2000) Bioremediation of petroleum hydrocarbon-contaminated soil by composting in biopiles. Environ Pollut 107: 245-254.

12. Sarkar D, Ferguson M, Datta R, Birnbaum S (2005) Bioremediation of petroleum hydrocarbons in contaminated soils: Comparison of biosolids addition, carbon supplementation, and monitored natural attenuation. Environ Pollut 136:187-195.

13. Filauro G, Andreotti G, Arlotti D, Reisinger H (1998) Blow out of Trecate 24 crude oil well: how bioremediation techniques are solving a major environmental emergency in a valuable agricultural area. Contaminated Soil 98: 403-412.

14. Porta A, Trovatto A, McCarthy K, Uhler A, Andreotti G (1997) Degradation of saturated and polycyclic aromatic hydrocarbons and formation of their metabolites in bioremediated crude oil-containing soils. In: Alleman B, Leeson A (Eds.), In Situ and on site Bioremediation: Battelle Press, Columbus, 1: 505-510.

15. Tamburini $D$ (1997) Evaluation of optimum hydrocarbon degradation conditions: a biotreatability study. In: Alleman B, Leeson A. (Eds.), In Situ and on site Bioremediation 1: 467-472.

16. Li L, Cunningham C, Pas V, Philp J, Barry D, et al. (2004) Field trial of a new aeration system for enhancing biodegradation in a biopile. Waste Manage 24 127-137.

17. Ting $\mathrm{Y}, \mathrm{Hu} \mathrm{H}$, Tan $\mathrm{H}$ (1999) Bioremediation of petroleum hydrocarbons in soil microcosms. Resour Environ Biotechnol 2: 197-218.

18. Nocentini M, Pinelli D, Fava F (2000) Bioremediation of a soil contaminated by hydrocarbon mixtures: the residual concentration problem. Chemosphere 41 : 1115-1123.

19. Namkoong W, Hwang E, Park J, Choi J (2002) Bioremediation of dieselcontaminated soil with composting. Environ Pollut 119: 23-31.

20. DOF (1994) Norma Oficial Mexicana NOM-092-SSA1-1994. Bienes y Servicios Método para la cuenta de bacterias aerobias en placa.

21. Fahnestock F, Wickramanayake R, Mayor W (1998) Biopile design, operation, and maintenance handbook for treating hydrocarbon-contaminated soils. Battelle press, USA.

22. DOF (2005) Norma Oficial Mexicana NOM-138-SEMARNAT/SS-2003. Límites máximos permisibles de hidrocarburos en suelos y las especificaciones para su caracterización y remediación.

23. Adams S (2002) Evaluation of microbial respiration and ecotoxicity in contaminated soils representative of the petroleum-producing region of southeastern Mexico. Terra 20: 253-265.

24. Greenwood P, Wibrow S, George S, Tibbett M (2009) Hydrocarbon biodegradation and soil microbial community response to repeated oil exposure. Org Geochem 40: 293-300 